\title{
Remineralization of bioavailable iron by a heterotrophic dinoflagellate
}

\author{
Allison A. Dalbec ${ }^{1}$, Benjamin S. Twining ${ }^{1,2, *}$ \\ ${ }^{1}$ Department of Chemistry and Biochemistry, University of South Carolina, 631 Sumter St., Columbia, \\ South Carolina 29208, USA \\ ${ }^{2}$ Present address: Bigelow Laboratory for Ocean Sciences, 180 McKown Point, PO Box 475, West Boothbay Harbor, \\ Maine 04575, USA
}

\begin{abstract}
The growth of phytoplankton in oligotrophic ocean waters is largely supported by nutrients remineralized through microzooplankton grazing. The bioavailability of the micronutrient Fe varies as a function of chemical speciation, but the speciation and bioavailability of Fe recycled by protozoan grazers is poorly characterized. We performed laboratory incubation experiments with cultured phytoplankton to examine the bioavailability of Fe produced by the heterotrophic dinoflagellate Oxyrrhis marina grazing on the centric diatom Thalassiosira pseudonana. Three different phytoplankton species (Thalassiosira weissflogii, Emiliania huxleyi and Nannochloris sp.) were grown on the remineralized $\mathrm{Fe}$, and Fe uptake rates (measured with the radiotracer ${ }^{55} \mathrm{Fe}$ ) and cell growth were used to assess bioavailability. Following $14 \mathrm{~h}$ of grazing, 1.09 to $1.11 \mathrm{nmol}{ }^{-1}$ Fe was remineralized in the presence of $O$. marina compared to $0.30-0.49 \mathrm{nmol} \mathrm{l}^{-1}$ released in grazer-free controls. The size fractionation of dissolved Fe was similar in the grazed (treatment) and non-grazed (control) cultures. The 0.02 to $0.2 \mu \mathrm{m}$ fraction was the largest (51 to $70 \%$ ), followed by the $<0.02 \mu \mathrm{m}$ fraction (32 to $44 \%$ ). Remineralized Fe was rapidly accumulated internally by all phytoplankton species, with most accumulation occurring during the first $14 \mathrm{~h}$. More Fe was accumulated in treatments compared to controls for all species, and cellular uptake rates were higher for remineralized Fe. These experiments confirm that microzooplankton grazing is a significant source of bioavailable Fe to marine phytoplankton in the open ocean.
\end{abstract}

KEY WORDS: Iron $\cdot$ Remineralization $\cdot$ Microzooplankton grazing $\cdot$ Recycle $\cdot$ Uptake Resale or republication not permitted without written consent of the publisher

\section{INTRODUCTION}

Iron is essential for processes such as photosynthesis, electron transport and $\mathrm{N}$ reduction, assimilation and fixation. The availability of Fe limits primary production in large areas of the world's oceans, including high nutrient, low chlorophyll (HNLC) regions in the Equatorial Pacific, Southern Ocean and subarctic North Pacific (de Baar et al. 2005). Because phytoplankton contribute to the removal of carbon from surface waters via sinking, Fe limitation of primary production has been hypothesized to impact global carbon biogeochemistry over glacial timescales (Martin 1990). It is therefore important to understand the mechanisms of Fe cycling and controls on Fe bioavailability in order to better understand the global carbon cycle.

Dissolved Fe occurs in the ocean primarily bound to organic ligands (Bruland \& Lohan 2003). Ligand concentrations have been found to co-vary with phytoplankton biomass in the water column, suggesting a biological source (e.g. Rue \& Bruland 1997, Boye et al. 2006, Gerringa et al. 2006). The equilibrium binding constants (i.e. stability constants) of natural ligands for Fe closely match those measured for model Fe chelators such as siderophores and tetrapyrrole compounds that may be released upon cell grazing and lysis (Witter et al. 2000). Indeed, these 2 groups of compounds are often invoked as comprising the pool of Fe-binding 
compounds in the ocean (e.g. Hutchins et al. 1999). Efforts to characterize Fe-binding ligands with chromatography and mass spectrometry have revealed the presence of functional groups characteristic of siderophores (Macrellis et al. 2001, Gledhill et al. 2004), but porphyrrin compounds have not yet been directly measured in open ocean waters. Refractory carboxyl-rich molecules may also constitute a significant portion of Fe-binding compounds (Hertkorn et al. 2006).

The magnitude of external Fe inputs to ocean waters varies widely across the global ocean. Most of the external Fe entering the open ocean is derived from the aeolian deposition of dust from arid continental regions; however, upwelling and horizontal advection can also be important sources. In low-Fe HNLC systems, remineralization may be the most significant source of dissolved Fe (Hutchins et al. 1993, Boyd et al. 2005). Previous studies have shown that remineralization can account for 30 to $100 \%$ of total Fe supplied to the euphotic zone (Bowie et al. 2001, Strzepek et al. 2005). Furthermore, the rapid cycling of Fe by grazing compared to the longer timescales of external particulate $\mathrm{Fe}$ input and dissolution indicates that much of the dissolved Fe present in HNLC waters passes through the biological remineralization pathway (Boyd et al. 2005).

Despite the importance of remineralization, the bioavailability of Fe recycled by microzooplankton grazers remains poorly characterized. Previous studies have demonstrated that Fe contained in phytoplankton prey can be remineralized by protozoan grazing (Hutchins \& Bruland 1994), and that this Fe is subsequently available to other phytoplankton (Hutchins et al. 1993). However, studies with model Fe-ligand complexes thought to be representative of those released following grazing suggest that phytoplankton groups may vary in their ability to access such compounds. In particular, Fe complexed to phaeophytin and protoporphyrin IX appears to be less bioavailable to cyanobacteria than to eukaryotic phytoplankton (Hutchins et al. 1999, Achilles et al. 2003). Sato et al. (2007) reported that Synechococcus growth was inhibited, relative to a UV-irradiated control, by organic Fe-binding ligands produced by a natural plankton community in the subarctic Pacific to a greater extent than the growth of eukaryotes Thalassiosira weissflogii or Micromonas pusilla. However, the addition of protoporphyrin IX actually enhanced the growth of Synechocccus, relative to the culture grown in unamended water, while effecting no change in the growth response of $T$. weissflogii and M. pusilla. Clearly additional data would be helpful to determine the bioavailablity of remineralized Fe.

We performed laboratory culture experiments to further investigate the relationship between protozoan grazer production of remineralized Fe and its bioavailability to eukaryotic marine phytoplankton. The radiotracer ${ }^{55} \mathrm{Fe}$ was used to follow short-term Fe uptake, and cell growth was also used to assess availability. The speciation of remineralized Fe was characterized using size-fractionation $(0.02,0.2,0.45 \mu \mathrm{m})$ in order to separate colloidal and truly dissolved $(<0.02 \mu \mathrm{m})$ forms of Fe. These experiments provide the first direct laboratory test of the bioavailability of Fe produced by protozoan grazing on phytoplankton.

\section{MATERIALS AND METHODS}

Acid washing. All plasticware was rigorously acidwashed prior to use to remove metal contamination. Polycarbonate (PC) flasks were sequentially soaked in $1 \%$ Micro soap $(24 \mathrm{~h}), 2 \mathrm{M}$ reagent $\mathrm{HCl}(48 \mathrm{~h})$ and $0.25 \mathrm{M}$ trace-metal grade $\mathrm{HNO}_{3}(48 \mathrm{~h})$ with copious rinsing with E-pure water $(>18 \mathrm{M} \Omega$ ) between each step. Plasticware was dried in a class 100 hood and then double-bagged in clean polyethylene bags for storage. All washing procedures were conducted in a class 1000 clean room wearing dust-free laboratory clothing and gloves.

Remineralization experiments. Remineralization experiments were designed to examine the bioavailability of Fe produced by microzooplankton grazing. All experiments used the same prey (Thalassiosira pseudonana, Provasoli-Guillard National Center for the Culture of Marine Phytoplankton, strain CCMP 1335) and grazer (Oxyrrhis marina, CCMP 604), but 3 different phytoplankton species were grown on the remineralized $\mathrm{Fe}$ to assess bioavailability: Thalassiosira weissflogii (CCMP 1336), Emiliania huxleyi (CCMP 375) and Nannochloris sp. (CCMP 513). These species represent a range of important taxonomic groups, habitats and cell sizes: T. weissflogii is a midsized $(\sim 12 \mu \mathrm{m})$ centric diatom isolated from a shallow coastal environment; E. huxleyi is a smaller $(\sim 5 \mu \mathrm{m})$ prymnesiophyte isolated from the Sargasso Sea; and Nannochloris is a small $(\sim 3 \mu \mathrm{m})$ chlorophyte isolated from the western equatorial Pacific Ocean. Each experiment involved 3 steps: (1) a growth step for radiolabeling $T$. pseudonana with ${ }^{55} \mathrm{Fe}_{\text {; }}$ (2) a grazing step when $T$. pseudonana were fed to O. marina; and (3) a 'regrowth' step when phytoplankton preacclimated to low-Fe conditions were added to grazing step filtrate to asses Fe bioavailability. The first 2 steps were performed separately for $T$. weissflogii and $E$. huxleyi (Expt 1) and Nannochloris sp. (Expt 2). Single flasks were used for the growth and grazing steps, but the grazing filtrates were split into triplicate flasks for the regrowth step. All steps were conducted in $0.2 \mu \mathrm{m}$ filtered oligotrophic surface seawater collected 
from the western North Atlantic $\left(25^{\circ} 38.023^{\prime} \mathrm{N}\right.$, $\left.77^{\circ} 26.804^{\prime} \mathrm{W}\right)$ using clean sampling techniques. Total dissolved Fe in this seawater (Bahama seawater, BSW) has been determined as $0.87 \pm 0.07 \mathrm{nmol} \mathrm{l}^{-1}$ utilizing competitive ligand equilibrium-cathodic stripping voltammetry (B.S.T. unpubl. data). When equilibrated with added EDTA (see 'Growth period'), this Fe is insufficient to support maximum growth rates of these phytoplankton species (data not shown). Stock cultures of all phytoplankton species were maintained at $20^{\circ} \mathrm{C}$ in enriched seawater media using sterile techniques, and $O$. marina was fed Dunalliela tertiolecta (CCMP 1320) prior to the grazing experiments.

Growth period. Thalassiosira pseudonana was radiolabeled in $0.2 \mu \mathrm{m}$ filtered BSW enriched with macronutrients, trace metals and vitamins. Final macronutrient concentrations were $100 \mathrm{mmol} \mathrm{l}^{-1} \mathrm{NO}_{3}{ }^{-}$, $100 \mu \mathrm{mol} \mathrm{l} \mathrm{l}^{-1} \mathrm{Si}(\mathrm{OH})_{4}$ and $10 \mu \mathrm{mol} \mathrm{l^{-1 }} \mathrm{PO}_{4}{ }^{3-}$. Metal stocks were added to total concentrations of $100 \mathrm{nmol}$ $\mathrm{l}^{-1} \mathrm{FeCl}_{3}, 2.7 \mathrm{nmol} \mathrm{l} \mathrm{l}^{-1} \mathrm{ZnSO}_{4}, 13 \mathrm{nmol} \mathrm{l} \mathrm{I}^{-1} \mathrm{MnCl}_{2}$, $4.2 \mathrm{nmol} \mathrm{l}^{-1} \mathrm{CoCl}_{2}, 1.1 \mathrm{nmol} \mathrm{l}^{-1} \mathrm{CuSO}_{4}, 0.1 \mu \mathrm{mol} \mathrm{l} \mathrm{l}^{-1}$ $\mathrm{Na}_{2} \mathrm{MoO}_{4}$ and $10 \mathrm{nmol} l^{-1} \mathrm{Na}_{2} \mathrm{SeO}_{3}$, and metal speciation was buffered with $100 \mu \mathrm{mol} \mathrm{l}^{-1}$ EDTA. Vitamin stocks were added to final concentrations of $0.5 \mu \mathrm{g} \mathrm{l^{-1 }}$ biotin, $0.55 \mu \mathrm{g} \mathrm{l}^{-1} \mathrm{~B}_{12}$ and $1 \mu \mathrm{g} \mathrm{l}^{-1}$ thiamine. The major nutrient stock solutions were treated with cleaned Chelex resin to remove trace metal contaminants, and media were microwaved for sterilization. A tracer level of ${ }^{55} \mathrm{FeCl}_{3}$ (>180 MBq $\mu \mathrm{mol}^{-1}$ ) was then added to culture media and equilibrated overnight with the media. For both experiments, the final concentration of ${ }^{55} \mathrm{Fe}$ added to the growth media was $15.5 \mathrm{nmol} \mathrm{l}^{-1}$. Stable $\mathrm{FeCl}_{3}$ was added $\left(85.5 \mathrm{nmol} \mathrm{l}^{-1}\right)$ to achieve a final total Fe concentration of $100 \mathrm{nmol} \mathrm{l}^{-1}$ in both experiments. Specific activities were calculated to account for both radioactive and stable $\mathrm{Fe}$ fractions present in the growth media.

Cells were radiolabeled with ${ }^{55} \mathrm{Fe}$ for $5 \mathrm{~d}$ (approximately 6 divisions). Cells were grown at $20^{\circ} \mathrm{C}$ under $150 \mu \mathrm{mol}$ photons $\mathrm{m}^{-2} \mathrm{~s}^{-1}$ on a $14 \mathrm{~h}$ light:10 h dark cycle. At the end of the labeling period, cultures were sampled for total radioactivity (dissolved + cellular), total cellular radioactivity (BSW rinsed filters), intracellular radioactivity (oxalate soaked filters) and cell concentration (cells $\mathrm{ml}^{-1}$ ). Total radioactivity was sampled by placing either 100 or $1000 \mu$ l of unfiltered sample in a $7 \mathrm{ml}$ scintillation vial with $6 \mathrm{ml}$ of scintillation cocktail (Ultima Gold-XR). Cellular radioactivity was assessed by collecting cells on $1 \mu \mathrm{m}$ PC membranes. After filtration, captured cells were rinsed with either BSW for total cellular Fe quotas or soaked for $5 \mathrm{~min}$ in an EDTA-oxalate solution ( $\mathrm{pH}$ 8) to remove extracellular Fe bound to the surface of the cells prior to rinsing with filtered BSW (Tovar-Sanchez et al. 2003). Thus, total cellular Fe quotas include both externally sorbed and intracellular Fe, while the oxalate treatment provides just the intracellular Fe quotas.

Prior to resuspension of Thalassiosira pseudonana cells for the grazing step, cells were soaked in oxalate solution 2 times in an effort to remove all external Fe from the cell surfaces. Cells were rinsed with BSW following each oxalate soak to remove mobilized Fe from cell surfaces. These soaks were performed to ensure that only Fe contained within cells could be actively remineralized by the grazers and to minimize release of $\mathrm{Fe}$ in the grazer-free controls. Rinsed cells were resuspended into filtered BSW and sampled for cell concentration and total and internal cellular Fe prior to being fed to Oxyrrhis marina.

Grazing period. Radiolabeled resuspended cells were diluted into 11 PC bottles containing sterilized BSW. Thalassiosira pseudonana was resuspended at concentrations between 84000 and 122000 cells ml $^{-1}$ (see Table 1). Oxyrrhis marina cells were gently centrifuged at $500 \mathrm{rpm}$ at $4^{\circ} \mathrm{C}$ for $30 \mathrm{~min}$ and resuspended in filtered BSW to concentrate cells prior to addition. $O$. marina cells were added to the treatment flasks at approximate concentrations of 5000 to 7000 cells ml $^{-1}$ and allowed to graze for $14 \mathrm{~h}$ in the dark at $20^{\circ} \mathrm{C}$. Control flasks received resuspended $T$. pseudonana but not $O$. marina grazers. At the end of the grazing period the flasks were sampled for $T$. pseudonana cell concentration and total and internal cellular Fe. Cells were then filtered out of control and treatment bottles with $0.45 \mu \mathrm{m}$ membranes (Whatman, polyethersulfone) and the filtrate was collected in separate flasks. Each filtrate was subsequently filtered serially through $0.22 \mu \mathrm{m}$ (Millipore Millex, polyethersulfone) and $0.02 \mu \mathrm{m}$ (Whatman Anotop, alumina matrix) filters. These size fractions were chosen to facilitate comparisons with published oceanographic Fe data. Triplicate samples of each size-fractionated filtrate were sampled for total radioactivity. Recycling rates (nmol l-1 $\mathrm{d}^{-1}$ ) were calculated using the $0.45 \mu \mathrm{m}$ filtrate from the end of grazing $(14 \mathrm{~h})$ by assuming linear rates over the course of $24 \mathrm{~h}$.

Regrowth period. Phytoplankton used in the regrowth step were pre-acclimated to low-Fe conditions in media prepared as before but containing only $10 \mathrm{nmol}^{-1}$ Fe. Cells were grown for a period of 3 to $6 \mathrm{~d}$ (depending on growth rate). Pre-acclimated cells were resuspended in sterile BSW and added at initial concentrations of 1000 to 2000 cells ml ${ }^{-1}$ to triplicate flasks containing the filtrate of either the grazing treatment or control flasks. Each flask also received enrichments of all macronutrients, vitamins and trace metals other than Fe to the same concentrations noted above. These additions were made to ensure that phytoplankton growth would not be limited by nutrients other than Fe. Cells were grown at $20^{\circ} \mathrm{C}$ under $150 \mu \mathrm{mol}$ photons 
$\mathrm{m}^{-2} \mathrm{~s}^{-1}$ on a $14 \mathrm{~h}$ light:10 h dark cycle. Cells were allowed to grow for $48 \mathrm{~h}$ and were sampled at 3 timepoints: 5 (Nannochloris sp.) or $14 \mathrm{~h}$ (Emiliania huxleyi and Thalassiosira weissflogii), $24 \mathrm{~h}$ and $48 \mathrm{~h}$. At each time-point, flasks were sampled for cell concentration and internal cellular Fe quotas on cells soaked in oxalate prior to rinsing with BSW as described above.

Analytical procedures. All liquid and membrane samples were counted in $7 \mathrm{ml}$ glass scintillation vials containing $6 \mathrm{ml}$ of scintillation cocktail (Ultima GoldXR). Radioactivity was assayed with a Packard TriCarb 2800TR liquid scintillation counter. All ${ }^{55} \mathrm{Fe}$ activities were corrected for quench. Samples were counted for $5 \mathrm{~min}$ and counting errors were typically $<5 \%$. Sorption of dissolved ${ }^{55} \mathrm{Fe}$ to filter membranes was assessed several times throughout the experiments. To do this, media filtrate $(<1 \mu \mathrm{m})$ was passed through $1 \mu \mathrm{m}$ membranes, which were rinsed with either BSW or oxalate and subsequently counted. Less than $1 \%$ of ${ }^{55} \mathrm{Fe}$ activity was retained on filters rinsed with either BSW or oxalate solution. Given the negligible adsorption of ${ }^{55} \mathrm{Fe}$, particulate samples were not corrected for filter blanks. Specific activities were calculated based on radioactive and stable $\mathrm{Fe}$ present in the growth media and were applied through each step of the experiments. Specific activities were not recalculated for the grazing and regrowth steps in order to focus on the behavior of the remineralized fraction.

Cell concentrations of Thalassiosira weissflogii and Emiliania huxleyi were measured with a Z2 Coulter Counter on samples preserved with $1 \%$ Lugols solution. Cell concentrations of Nannochloris sp. were assessed by epifluorescence microscopy. Samples were preserved in $1 \%$ glutaraldehyde, collected on $0.22 \mu \mathrm{m}$ black PC filters and mounted on slides. Cell counts were performed with a Leica DMI 6000B inverted microscope following excitation with blue light. Random cell counts were performed on 10 frames per slide to determine cell concentration. At least 100 cells were counted per time-point and treat- ment, resulting in a precision of $\pm 20 \%$ (Guillard \& Sieracki 2005). Mean cell concentrations and Fe uptake rates were compared between treatments and controls using the non-parametric Wilcoxon test (Zar 1996).

\section{RESULTS}

Thalassiosira pseudonana was radiolabeled with ${ }^{55} \mathrm{Fe}$ prior to the grazing experiments. Cell cultures grew to a concentration of approximately 250000 cells $\mathrm{ml}^{-1}$ during both experiments, and approximately $10 \%$ of ${ }^{55} \mathrm{Fe}$ in the media was accumulated by the cells during the growth step. At the end of radiolabeling, total (extracellular plus intracellular) Fe quotas for $T$. pseudonana ranged from 79 to $140 \mathrm{amol} \mathrm{Fe} \mathrm{cell}{ }^{-1}$, and intracellular Fe ranged from 37 to $40 \mathrm{amol} \mathrm{Fe} \mathrm{cell}{ }^{-1}$ for both experiments. Approximately 52 to $72 \%$ of the total Fe was externally bound. Following 2 sequential oxalate soaks (each followed by resuspension in BSW), $<15 \%$ of the ${ }^{55} \mathrm{Fe}$ in the T. pseudonana cells was externally bound. Therefore, desorption of extracellular Fe during grazing was likely negligible. Following resuspension of cells into the grazing media, variability was observed in the measured intracellular Fe quotas of the prey cells. Cell quotas in Expt 1 closely matched those measured at the end of growth, while cell quotas appeared to drop to 15 amol Fe cell ${ }^{-1}$ following resuspension in Expt 2. This change was observed in both the treatment and control flasks of Expt 2.

During the grazing period, Oxyrrhis marina actively ingested the radiolabeled Thalassiosira pseudonana cells (Table 1). Some T. pseudonana growth was observed in the control flask of Expt 1, and this growth was corrected for when calculating the concentration of cells consumed during the $14 \mathrm{~h}$ grazing period. $O$. marina consumed 65000 and 71000 cells ml$^{-1}$ in the 2 experiments and grew between 1400 and 1700 cells ml $^{-1}$. Particulate radioactivity decreased by

Table 1. Experimental conditions of protozoan remineralization experiments. The grazing incubations lasted $14 \mathrm{~h}$, and remineralization rates were calculated by linearly extrapolating the measured rates to a $24 \mathrm{~h}$ day

\begin{tabular}{|c|c|c|c|c|}
\hline \multirow[t]{2}{*}{ Parameter } & \multicolumn{2}{|c|}{ Experiment 1} & \multicolumn{2}{|c|}{ Experiment 2} \\
\hline & Treatment & Control & Treatment & Control \\
\hline Initial T. pseudonana conc. (cells $\mathrm{ml}^{-1}$ ) & 90556 & 84444 & 122222 & 118333 \\
\hline Final T. pseudonana conc. (cells ml ${ }^{-1}$ ) & 48333 & 112777 & 57037 & 118518 \\
\hline Cells grazed $\left(\right.$ cells ml $\left.{ }^{-1}\right)$ & 70556 & - & 65370 & - \\
\hline Initial particulate radioactivity $\left(\mathrm{dpm} \mathrm{ml} \mathrm{m}^{-1}\right.$ ) & 3520 & 3698 & 1537 & 1412 \\
\hline Final particulate radioactivity $\left(\mathrm{dpm} \mathrm{ml}^{-1}\right)$ & 2761 & 3783 & 910 & 1485 \\
\hline Iron remineralized during incubation $\left(\mathrm{nmol} \mathrm{l}^{-1}\right)$ & 1.09 & 0.49 & 1.11 & 0.30 \\
\hline Remineralized iron $\left(\mathrm{nmol} \mathrm{l}^{-1}\right)$ & 0.60 & - & 0.81 & - \\
\hline Iron remineralization rate $\left(\mathrm{nmol} \mathrm{l}^{-1} \mathrm{~d}^{-1}\right)$ & 1.03 & - & 1.39 & - \\
\hline
\end{tabular}



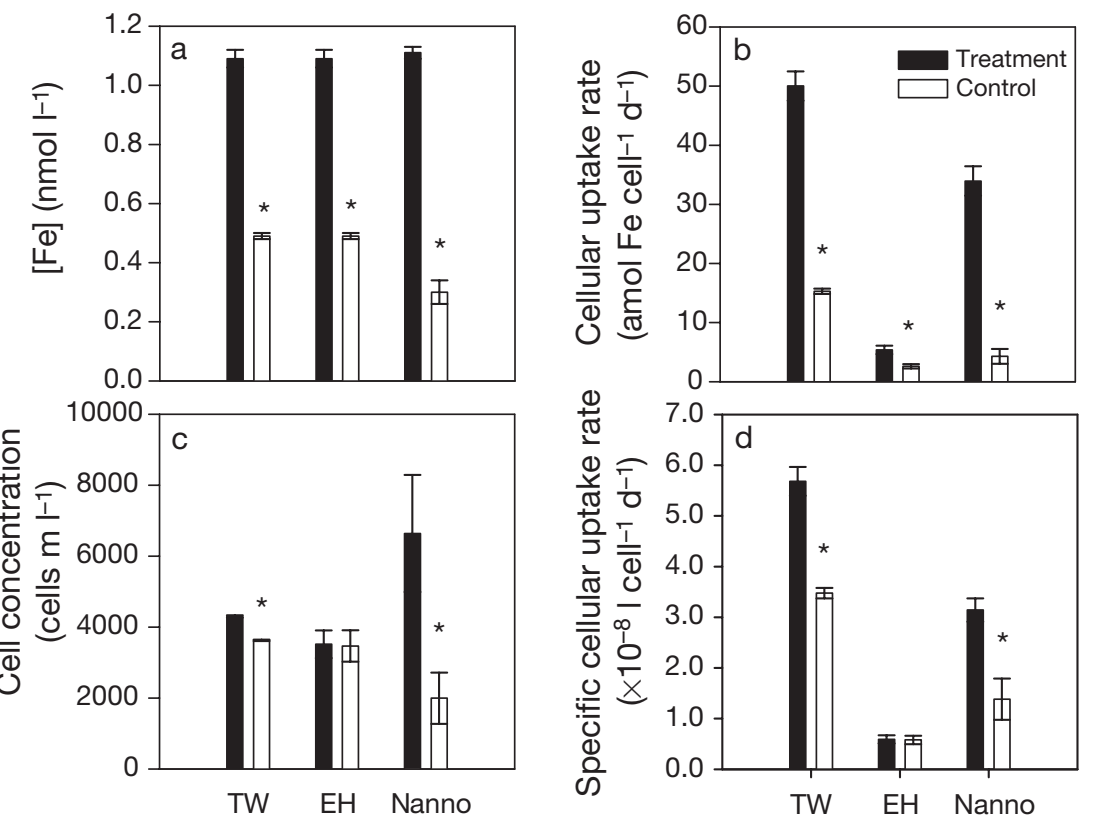

Fig. 1. (a) Concentrations of $<0.45 \mu \mathrm{m}$ remineralized Fe in experimental filtrates, (b) short-term (5 to $14 \mathrm{~h}$ ) intracellular uptake rates of Fe, (c) $48 \mathrm{~h}$ cell growth yields and (d) specific intracellular uptake rates for Thalassiosira weissflogii (TW), Emiliana huxleyi (EH) and Nannochloris sp. (Nanno) cultures in remineralization experiments. Intracellular uptake rates were measured on cells soaked in an oxalate solution to remove externally bound Fe prior to counting. Bars are means $( \pm \mathrm{SD})$ of triplicate flasks. *: Statistically significantly different means for corresponding treatments and controls (Wilcoxon test, $\mathrm{p}<0.10$ )
Clear differences were observed in the uptake of remineralized $\mathrm{Fe}$ by phytoplankton added to the control and treatment filtrates. The Fe remineralized by Oxyrrhis marina was rapidly accumulated internally by the phytoplankton. Cellular uptake rates ranged 10-fold, from 5.4 amol Fe cell ${ }^{-1}$ $\mathrm{d}^{-1}$ for Emiliania huxleyi to $50.0 \mathrm{amol}$ Fe cell ${ }^{-1} \mathrm{~d}^{-1}$ for Thalassiosira weissflogii (Table 2). These differences are largely due to differences in cell size (volume); C-normalized Fe uptake rates were less divergent (Table 2). More notably, for each taxon, significantly more Fe was accumulated during the first 5 to $14 \mathrm{~h}$ by cells in the grazing filtrate compared to cells in the controls (Wilcoxon test, $\mathrm{p}<0.10$ ) (Fig. 1b). Cellular Fe uptake rates were $3.3,2.1$ and 7.9 times higher in the grazing filtrate than in the control filtrate for $T$. weissflogii, E. huxleyi and Nannochloris sp., respectively. Because remineralized Fe concentrations were also higher in the treatments than in the controls, specific cellular uptake rates were calculated 22 to $41 \%$ in the grazing treatments but was unchanged in the control flasks. By the end of the grazing period, 1.09 to $1.11 \mathrm{nmol} \mathrm{l^{-1 }}$ Fe had been released in the treatments and 0.30 to 0.49 nmol $\mathrm{l}^{-1}$ in the control flasks (Table 1, Fig. 1a). Remineralized Fe concentrations in the treatments were calculated to be 0.60 and $0.81 \mathrm{nmol} \mathrm{l}^{-1}$ for the 2 experiments after correction for Fe released in the grazer-free controls, with corresponding recycling rates of 1.03 and $1.39 \mathrm{nmol} \mathrm{l^{-1 }} \mathrm{d}^{-1}$. Including the $\mathrm{Fe}$ present in the BSW media used for the grazing experiments, total dissolved Fe concentrations in the grazing treatment filtrates were 1.4 and 1.7-fold higher than in the control filtrates. The size fractionation of remineralized Fe following the grazing period was similar for the 2 experiments (Fig. 2). In both experiments, the 0.02 to $0.22 \mu \mathrm{m}$ fraction was the largest (51 to $70 \%$ ), followed by the $<0.02 \mu \mathrm{m}$ fraction (32 to $44 \%$ ). The 0.22 to $0.45 \mu \mathrm{m}$ fraction was uniformly the smallest ( -2 to $8 \%$ ) for both control and treatment. by normalizing cellular Fe uptake rates to remineralized Fe concentrations. Specific uptake rates of grazerregenerated $\mathrm{Fe}$ were significantly higher (Wilcoxon
Table 2. Internal cellular uptake rates of remineralized Fe by Thalassiosira weissflogii, Emiliania huxleyi and Nannochloris sp. The rates measured during the present study are shown as means \pm SD of triplicate flasks. Rates are presented both on a cellular basis (amol Fe cell ${ }^{-1} \mathrm{~d}^{-1}$ ) and normalized to cell biomass ( $\mu$ mol Fe mol $\mathrm{C}^{-1} \mathrm{~d}^{-1}$ ). The former are converted to the latter using cell $\mathrm{C}$ quotas of 7.5, 1.8 and $2.3 \mathrm{pmol} \mathrm{C}$ cell $^{-1}$ for T. weissflogii, E. huxleyi and Nannochloris sp., respectively. These values were measured directly with ${ }^{14} \mathrm{C}$ for the latter 2 species (authors' unpubl. data); the $T$. weissflogii $\mathrm{C}$ quota was taken from Sunda \& Huntsman (1995). Published cellular uptake rates are also shown for T. weissflogii and E. huxleyi: Sunda \& Huntsman (1995) measured steadystate uptake rates in media containing 2 and $11 \mathrm{nM}$ total Fe for E. huxleyi

T. weissflogii over $2 \mathrm{~d}$ in media containing $10 \mathrm{nM}$ porphyrin-Fe complexes

\begin{tabular}{|c|c|c|c|c|}
\hline & \multicolumn{2}{|c|}{ Present study } & \multirow{2}{*}{$\begin{array}{c}\text { Sunda \& } \\
\text { Huntsman (1995) }\end{array}$} & \multirow{2}{*}{$\begin{array}{l}\text { Hutchins } \\
\text { et al. (1999) }\end{array}$} \\
\hline & Treatment & Control & & \\
\hline \multicolumn{5}{|l|}{ amol Fe cell ${ }^{-1} d^{-1}$} \\
\hline T. weissflogii & $50.0 \pm 2.5$ & $15.3 \pm 0.5$ & 30 & $65-70$ \\
\hline E. huxleyi & $5.4 \pm 0.7$ & $2.6 \pm 0.4$ & 0.75 & - \\
\hline Nannochloris sp. & $33.9 \pm 2.5$ & $4.3 \pm 1.3$ & - & - \\
\hline \multicolumn{5}{|c|}{$\mu \mathrm{mol}$ Fe mol $\mathrm{C}^{-1} \mathbf{d}^{-1}$} \\
\hline T. weissflogii & $6.7 \pm 0.3$ & $2.0 \pm 0.1$ & - & - \\
\hline E. huxleyi & $3.0 \pm 0.4$ & $1.4 \pm 0.2$ & - & - \\
\hline Nannochloris sp. & $14.7 \pm 1.1$ & $1.9 \pm 0.6$ & - & - \\
\hline
\end{tabular}
and T. weissflogii, respectively; Hutchins et al. (1999) measured Fe uptake by 


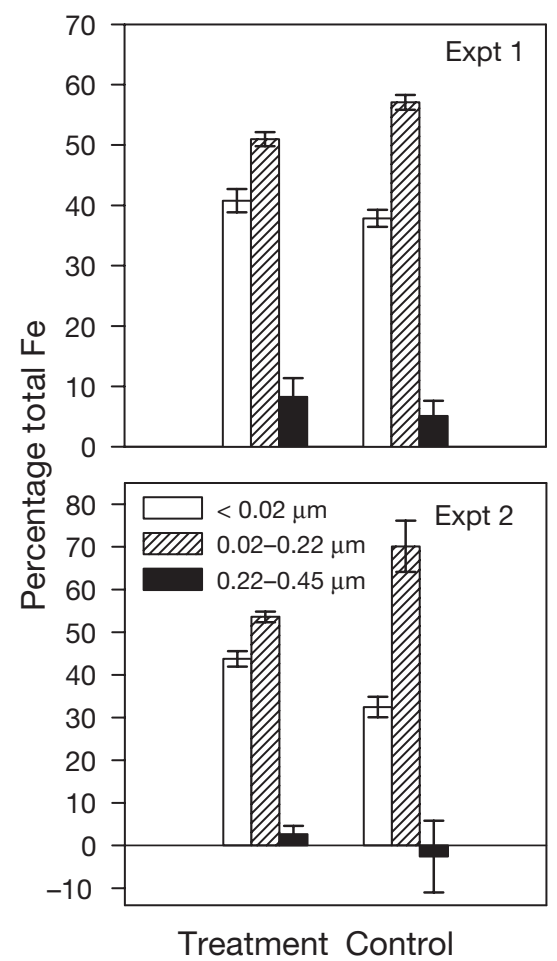

Fig. 2. Size fractionation of dissolved Fe released during grazing treatment and control incubations in Expts 1 \& 2. Bars are means $( \pm \mathrm{SD})$ of triplicate flasks, with the exception of Expt 2 control, which plots mean ( \pm range/2) of duplicate flasks

test, $\mathrm{p}<0.10$ ) than specific uptake rates in the controls for T. weissflogii and Nannochloris sp., but not for $E$. huxleyi (Fig. 1d). All of the observed Fe accumulation occurred during the first $14 \mathrm{~h}$ in both the treatments and controls with the exception of the E. huxleyi control, in which cells accumulated $26 \%$ more Fe by $48 \mathrm{~h}$ (Fig. 3). The amount of ${ }^{55} \mathrm{Fe}$ accumulated by each cell in the treatment filtrates decreased over the regrowth period for all species, presumably as a result of biodilution during cell growth. After $48 \mathrm{~h}$ of growth, internal Fe quotas were similar in cells grown in either treatment or control filtrate for all species.

Remineralized $\mathrm{Fe}$ supported the growth of each of the phytoplankton species (Fig. 4). Cell concentrations in the grazing filtrate increased 1.7- to 4.4-fold during the $48 \mathrm{~h}$ regrowth period. Growth of Thalassiosira weissflogii and Emiliania huxleyi was also observed in the control filtrate, while Nannochloris sp. did not grow in the control filtrate. T. weissflogii and Nannochloris sp. both achieved significantly higher cell yields in the grazing filtrate compared to the controls after $48 \mathrm{~h}$ (Wilcoxon test, p < 0.10) (Fig. 1c). E. huxleyi showed no distinguishable difference in cell yield between treatment and control despite having initially accumulated more Fe in treatment cells.
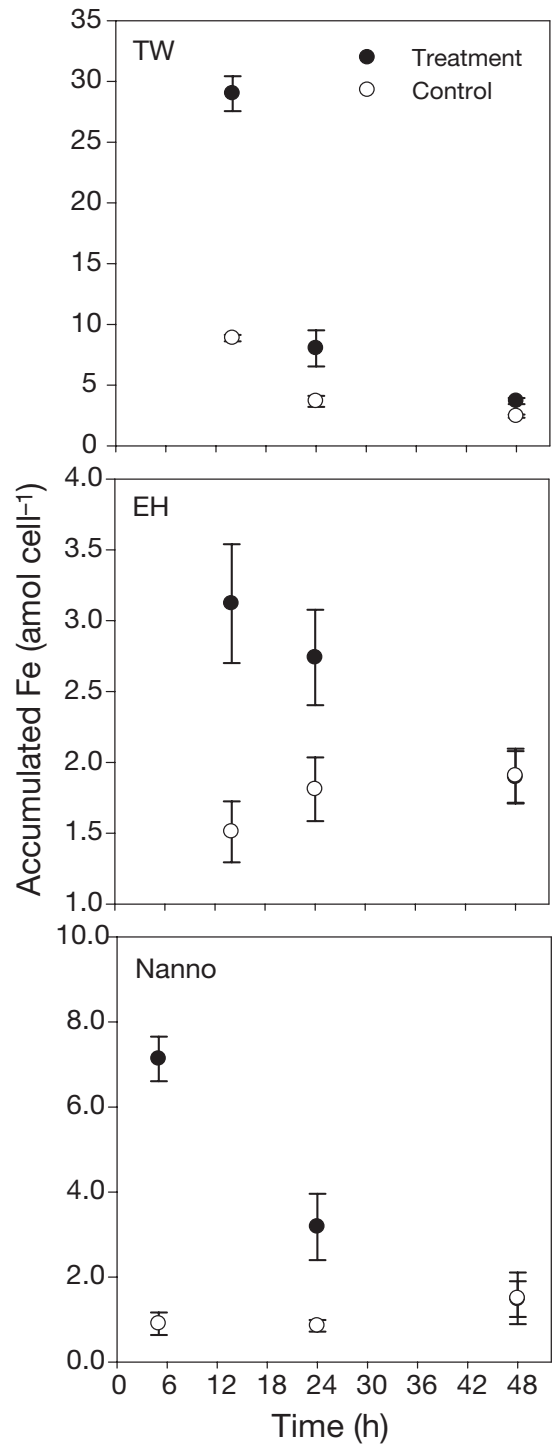

Fig. 3. Cellular Fe accumulated internally by Thalassiosira weissflogii (TW), Emiliania huxleyi (EH) and Nannochloris sp. (Nanno) during regrowth period. Points are means $( \pm \mathrm{SD})$ of triplicate flasks. Internal accumulation was measured on cells soaked in an oxalate solution to remove externally bound Fe prior to counting

\section{DISCUSSION}

These experiments demonstrate that Fe is remineralized during grazing of the centric diatom Thalassiosira pseudonana by the heterotrophic dinoflagellate Oxyrrhis marina. Furthermore, the recycled Fe is bioavailable to several model phytoplankton organisms on relatively short time scales (hours). The present study complements previous work which described rapid remineralization and cycling of Fe from phytoplankton and bacterial prey by protozoa without directly assessing bioavailability (Hutchins \& Bruland 


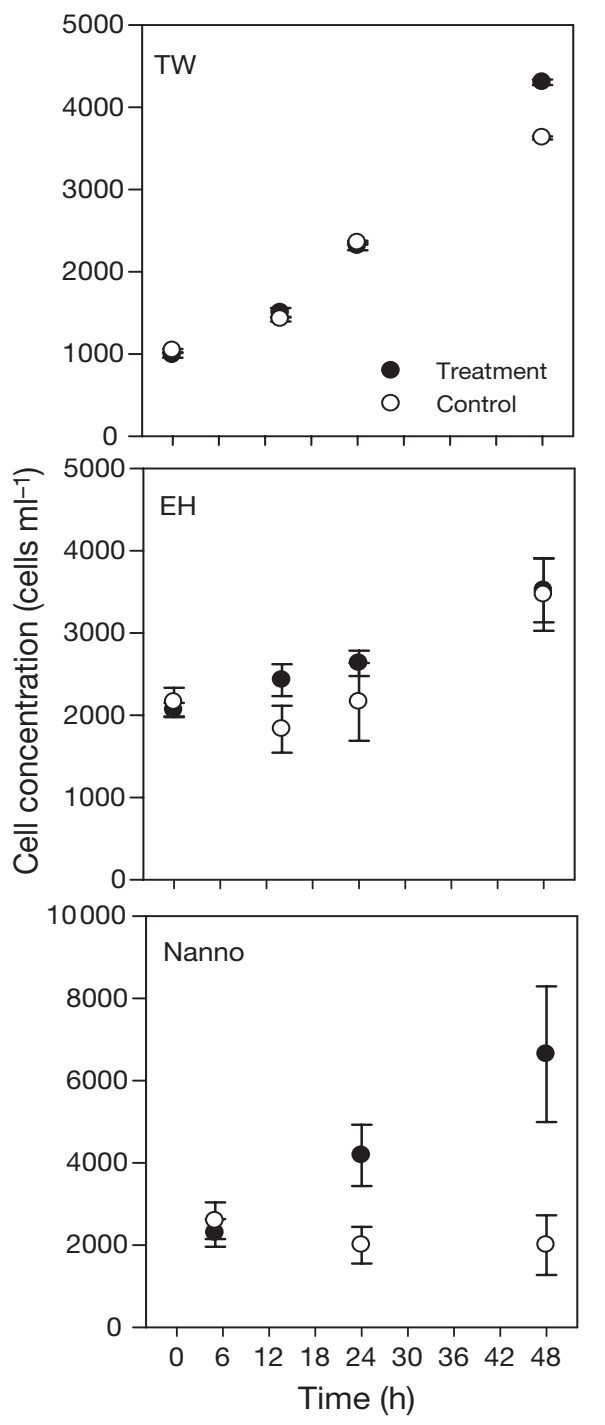

Fig. 4. Growth of Thalassiosira weissflogii (TW), Emiliania huxleyi (EH) and Nannochloris sp. (Nanno) during regrowth period. Points are means $( \pm \mathrm{SD})$ of triplicate flasks

1994, Barbeau et al. 2001a), as well as that which illustrated the capability of protozoan grazers to produce bioavailable Fe from refractory inorganic Fe-oxyhydroxide colloids (Barbeau et al. 1996). The present study demonstrates that bioavailable Fe can also be produced by a protozoan grazer ingesting live phytoplankton prey cells, as commonly occurs in natural systems. Together, these studies point to a clear and significant role for protozoa in ocean Fe cycling.

\section{Bioavailability of remineralized Fe}

The most direct indicator of bioavailability in these experiments is the internal accumulation of Fe by the added phytoplankton cells over short time scales. Cellular Fe uptake (normalized to time to eliminate differences in uptake time-points between the experiments) was significantly higher for each taxon in the presence of remineralized Fe. Further, the uptake rates measured in the treatments were relatively fast compared to published rates measured under comparable conditions (Table 2). Both of these comparisons indicate that remineralized Fe is bioavailable to the 3 species used here. Metal uptake by phytoplankton is generally thought to follow Michaelis-Menten uptake kinetics, in which the uptake rate increases as a function of the bioavailable Fe concentration until uptake sites become saturated. The total dissolved Fe concentrations in the experimental flasks were lower than or comparable to the available half-saturation constants ( $K_{\mathrm{s}}$, based on total dissolved Fe) reported for some of these species (Hudson \& Morel 1990, Sunda \& Huntsman 1995, Timmermans et al. 2001), suggesting that the elevated uptake rates in the treatment filtrates may have resulted from higher dissolved Fe concentrations. However, uptake rates of remineralized Fe normalized to ambient concentrations (specific cellular Fe uptake rates) were still significantly higher than controls for Thalassiosira weissflogii and Nannochloris sp. If the Fe concentrations in the flasks were above $K_{\mathrm{s}}$ then normalization to ambient dissolved Fe would serve to 'over-correct' the uptake rates in the higher Fe treatments. Therefore, the specific cellular uptake rates provide a fairly conservative point of comparison between the treatments and controls. These results suggest that remineralized Fe may actually be more bioavailable to Nannochloris sp. and $T$. weissflogii than Fe released by $T$. pseudonana independent from grazing, while Emiliania huxleyi appears able to access remineralized and exuded $\mathrm{Fe}$ to an equal extent. None of the 3 species accumulated remineralized Fe at rates slower than the control Fe.

Interspecific comparisons of remineralized $\mathrm{Fe}$ uptake rates must be approached with caution because of uncertainty regarding the Fe limitation status of each species. Phytoplankton can accumulate Fe via several mechanisms, including relatively non-specific metal transport proteins and inducible high-affinity pathways potentially involving cell surface reductases and oxidases (Sunda \& Huntsman 1998, Maldonado \& Price 2001). The latter mechanisms may only be upregulated under Fe limitation (Maldonado \& Price 2001). Cultures of all 3 species were grown under lowFe conditions prior to inoculating the regrowth flasks, but precise cell counts were not conducted to enable confirmation of Fe-limitation of each species. Therefore, it is not possible to directly compare the uptake effects in the 3 species. Emiliania huxleyi may not have accumulated remineralized Fe at an elevated rate (rel- 
ative to the control) because it was not Fe-limited and therefore had not induced its high-affinity uptake system. Regardless of the mechanism, it is significant that each taxon was able to accumulate the remineralized Fe. Cellular Fe accumulation was at least 2-fold higher in the remineralization treatments by the first timepoint for all species (Fig. 3). Future work should focus on determining the biochemical mechanism of $\mathrm{Fe}$ uptake under these conditions.

Cell growth was enhanced by the presence of remineralized Fe for Thalassiosira weissflogii and Nannochloris sp.; the growth of Emiliania huxleyi was not enhanced by the remineralized Fe. However, the growth results may reflect differences in minimum Fe quotas of the 3 species and therefore differences in their Fe limitation status. It has been shown that phytoplankton from low-Fe ocean environments can reduce cellular Fe requirements through changes in their biochemical components (e.g. La Roche et al. 1996, Peers \& Price 2006), and Sunda \& Huntsman (1995) found that the coastal species $T$. weissflogii required approximately 5 -fold more Fe for growth than an oceanic strain of E. huxleyi (different from that used here). Thus, the differences in growth response to the remineralized Fe by the 3 species should not be directly compared. A more useful comparison is between the treatment and control: cell growth was equal or greater in the presence of remineralized Fe for all species. This is in contrast to the findings of Sato et al. (2007), who observed a decrease in the growth of phytoplankton in the presence of remineralized $\mathrm{Fe}$ (and Fe-binding ligands).

The presence of unlabeled Fe in the seawater media could have impacted the growth responses of the 3 species. This Fe occurred at a similar concentration $(0.87 \mathrm{nM})$ to the remineralized $\mathrm{Fe}$ in the treatments, and it occurred at a higher concentration than found in the control flasks. This Fe is unlikely to have equilibrated with the ${ }^{55} \mathrm{Fe}$ from the grazing flasks over the short period of the uptake measurements, but it may have equilibrated during the longer growth period. The presence of this fraction could have contributed to the growth observed in the Thalassiosira weissflogii and Emiliania huxleyi control flasks. Despite the presence of this Fe in both the treatment and control flasks, the growth of $T$. weissflogii and Nannochloris sp. was significantly elevated by the presence of remineralized Fe.

These results support previous studies which have concluded that eukaryotic phytoplankton-diatoms in particular-can readily access remineralized Fe. Hutchins et al. (1999) found that cultured diatoms and natural eukaryotic phytoplankton accumulated Fe from phaeophytin and protoporphyrin complexes presumed to be representative of remineralized Fe. They further observed that the relative availability of inorganic Fe and Fe-porphyrin compounds varied between species, and found that Thalassiosira weissflogii accumulated protoporphyrin $\mathrm{Fe}$ more rapidly than inorganic Fe. Recent field results from the western subarctic Pacific Ocean also show that $T$. weissflogii can access Fe remineralized by microzooplankton grazers (Sato et al. 2007). These researchers found only minor decreases in $T$. weissflogii growth in filtrate containing excess Fe-binding ligands produced by protozoan grazers. Furthermore, the addition of protoporphyrin IX to UV-irradiated filtrate, which should be free of organic Fe-binding compounds, had a minimal effect on Fe bioavailability and cell growth of $T$. weissflogii. Sato et al. (2007) did observe a depression in growth of the small (2 to $3 \mu \mathrm{m})$ prasinophyte Micromonas pusilla in filtrates from $8 \mathrm{~d}$ microzooplankton grazing incubations, but cells grew even more poorly in the same water following UV-irradiation of organic ligands. This suggests that the presence of some other grazing product limited growth instead of Fe speciation and availability.

Iron speciation and bioavailability may have been impacted by the presence of heterotrophic bacteria or viruses in the cultures. Considerable efforts were made to minimize the presence of these groups, including the use of sterile techniques during media preparation and handling steps. Still, it is unlikely that any of the cultures were axenic. Heterotrophic bacteria present in the growth media may have incorporated ${ }^{55} \mathrm{Fe}$ and been inadvertently transferred to the grazing cultures, introducing non-algal prey to the dinoflagellate grazers. Bacteria present in the regrowth media could have impacted dissolved Fe speciation through the release of siderophores or other Fe-binding compounds. Such compounds would likely serve to reduce Fe availability to the algae. Bacteria could also have accumulated remineralized $\mathrm{Fe}$ during the regrowth step, artificially increasing the appearance of Fe uptake by the phytoplankton. Additionally, viruses could have been present in the media and might have contributed to cell lysis during the grazing steps, particularly in the controls. However, we expect these effects to be relatively minor, as most bacterial cells and viruses would be expected to pass through the $1 \mu \mathrm{m}$ membranes used to resuspend radiolabeled Thalassiosira pseudonana. Bacteria and viruses are also unlikely to have been sedimented during the gentle centrifugation conditions $(52 \times g)$ used to concentrate and separate Oxyrrhis marina prior to the grazing step. Supporting this, no cell loss was observed in the control flasks.

The addition of EDTA to the regrowth media may have affected the bioavailability of the remineralized $\mathrm{Fe}$, but we believe this effect would be minimal during the 5 to $14 \mathrm{~h}$ period over which uptake was assessed (Figs. 1b, d). EDTA occurs primarily bound to Ca and 
$\mathrm{Mg}$ in seawater media, and the presence of Ca would significantly slow coordination reactions with remineralized Fe (Hering \& Morel 1989). Hering \& Morel (1989) found that $\mathrm{Cu}$ exchanged from calcein to EDTA on the timescales of hours to days in the presence of $\mathrm{Ca}$ at seawater concentrations, and predicted longer ligand equilibration times for Fe. It is therefore unlikely that EDTA affected the speciation of Fe bound to native ligands during the relatively short time frames of the uptake experiments. Furthermore, complexation of remineralized Fe by EDTA would be expected to reduce Fe bioavailability. Indeed, Castruita et al. (2008) found that growth rates of Thalassiosira weissflogii grown on Fe-ferritin complexes were reduced as EDTA was increased from 50 to $200 \mu \mathrm{mol} \mathrm{l^{-1 }}$. Therefore, the measured Fe uptake indicates availability of the natural Fe-ligand complexes. Cellular Fe uptake rates measured in the grazing filtrate are higher than minimum Fe uptake rates reported elsewhere for Emiliania huxleyi and T. weissflogii in seawater media containing similar concentrations of EDTA (Sunda \& Huntsman 1995). Additionally, T. weissflogii Fe uptake rates reported here are similar to uptake rates from porphyrin-Fe complexes for the same species (Hutchins et al. 1999).

Although EDTA could have altered Fe speciation by the end of the $48 \mathrm{~h}$ regrowth period, nearly all of the accumulation of remineralized ${ }^{55} \mathrm{Fe}$ occurred during the first 5 to $14 \mathrm{~h}$. Following this initial period, accumulated Fe cell ${ }^{-1}$ decreased in all 3 taxa (Fig. 3), probably as a result of biodilution (growth) and cell efflux. Complexation by EDTA may have become increasingly important to ${ }^{55} \mathrm{Fe}$ speciation during the latter part of the regrowth experiments; however, Thalassiosira weissflogii and Nannochloris sp. both grew better in the presence of remineralized Fe than in the controls, even with EDTA added to both treatments. The presence of EDTA somewhat limits our ability to interpret the mechanisms of ${ }^{55} \mathrm{Fe}$ accumulation over the full $48 \mathrm{~h}$ course of the experiments. However, EDTA was present in both treatments and controls, so the significantly higher rates observed in the treatments vs. controls during the initial incubation period is clear evidence of the availability of the remineralized fraction.

The mechanism by which eukaryotic phytoplankton access remineralized $\mathrm{Fe}$ is not known. As noted above, tetrapyrrole compounds such as phaeophytin and protoporphyrin are often considered as appropriate model compounds for Fe-binding ligands produced by protozoa-mediated phytoplankton cell lysis (Hutchins et al. 1999, Witter et al. 2000). Direct uptake of porphyrin-Fe (heme) has been demonstrated for certain pathogenic bacteria and free-living eukaryotes (Mazmanian et al. 2003, Rao et al. 2005), but it is unlikely that Fe-por- phyrin complexes are transported across the cell membrane by phytoplankton. It is possible that eukaryotic phytoplankton access porphyrin-Fe complexes following Fe reduction and dissociation by membrane-bound ferrireductases, as shown for siderophore-Fe complexes (Soria-Dengg \& Horstmann 1995, Hutchins et al. 1999, Maldonado \& Price 2001). Iron bound to organic ligands may also become more bioavailable following photo-reduction. Maldonado et al. (2005) observed that Fe bound to natural ligands in the subantarctic waters off New Zealand was significantly more bioavailable to resident phytoplankton in the presence of ambient sunlight.

\section{Mechanisms of remineralization}

The chemical mechanisms by which intracellular phytoplankton Fe compounds are converted into bioavailable Fe species through protozoan grazing are also not known. Barbeau \& Moffett (1998) and Barbeau et al. (2001a) suggested that inorganic Fe colloids are dissolved under acidic conditions $(\mathrm{pH} \sim 2)$ within the protozoan digestive vacuole, and a similar mechanism may apply to biological prey particles. Iron inside the prey cells is incorporated into numerous metalloproteins, including tetrapyrrole and Fe-S molecules and, potentially, storage compounds such as ferritin. Iron may be released from these compounds at low $\mathrm{pH}$, particularly if the proteins are unfolded, exposing internal Fe sites to acidic conditions. This could result in the production of either inorganic Fe or organic Fe complexes, depending upon whether the Fe is retained in smaller organic moieties such as heme groups. Alternatively, Fe-containing molecules may be released intact when food vacuoles are ejected from the protozoan cell.

Microzooplankton grazing may also result in the production of excess Fe-binding ligands through the conversion of chlorophyll to phaeophytin via the release of the $\mathrm{Mg}^{2+}$ ion under acidic vacuole conditions. Protozoa have been shown to produce phaeophytin (Strom 1993), and the empty porphyrin ring of phaeophytin is capable of forming strong complexes with $\mathrm{Fe}^{3+}$ (Witter et al. 2000). Phaeophytin released during grazing could subsequently bind with free or inorganic Fe released independently. Production of free Fe-binding ligands in excess of remineralized Fe has been observed during microzooplankton grazing experiments in the subarctic Pacific Ocean (Sato et al. 2007).

Although the chemical form of the remineralized Fe is largely uncharacterized, colloidal size-fractionation measurements performed at the end of the grazing period in the present study indicate that recycled Fe occurs in several forms. Approximately $40 \%$ of the dis- 
solved $(<0.45 \mu \mathrm{m})$ Fe passed through a $0.02 \mu \mathrm{m}$ membrane, while the majority $(\sim 50 \%)$ was retained. This is similar to the results of Barbeau et al. (2001a), who reported that $46 \%$ of the dissolved $(<0.2 \mu \mathrm{m})$ Fe produced by the heterotrophic flagellate Cafeteria sp. passed through a $10 \mathrm{kDa}$ membrane. This similarity is perhaps fortuitous given the interspecific differences in colloidal Fe production noted by the authors and the different prey organisms used in the 2 studies (small centric diatoms vs. heterotrophic bacteria). Still, the Fe remineralized by grazing processes is likely a mixture of truly 'dissolved' Fe bound to inorganic and organic ligands as well as colloidal (20 to $200 \mathrm{~nm}$ ) and particulate $(>0.45 \mu \mathrm{m})$ forms. Only a small fraction $(<10 \%)$ of the recycled Fe was found in the larger colloidal fraction (200 to $450 \mathrm{~nm}$ ).

The colloidal fraction would include Fe associated with undigested organelles and membranes and $\mathrm{Fe}$ sorbed to cell-derived colloidal material following egestion. Gobler et al. (1997) reported nearly all of the Fe released from viral lysis of Aureococcus anophagefferens to be initially particulate $(>0.2 \mu \mathrm{m})$, and suggested that this Fe may be associated with aggregations of proteins, nucleic acids and other subcellular components. Protozoan grazing might be expected to produce a higher fraction of dissolved Fe than viral lysis because of the enzymatic activity and acid conditions associated with digestive vacuoles, and indeed we observed significantly more $<0.2 \mu \mathrm{m}$ Fe than Gobler et al. (1997). However, a separate study of Fe remineralization by viral lysis found that $\mathrm{Fe}$ was predominately released $(82 \%)$ in the $<3 \mathrm{kDa}$ fraction following viral lysis of Synechococcus sp. (Poorvin et al. 2004), making it difficult to draw conclusions from these comparisons.

In addition to $\mathrm{Fe}$ actively remineralized by dinoflagellate grazing, Fe was also remineralized in the control flasks containing only Thalassiosira pseudonana. Prior to grazing, the prey cells were treated twice with an oxalate rinse to remove externally bound $\mathrm{Fe}$, and only 2 to $12 \%$ of the extracellular Fe remained following these soaks. Therefore, the measured remineralization cannot be explained by simple desorption following resuspension. Iron can be lost from phytoplankton following viral lysis (Poorvin et al. 2004), and viruses may have been present in the waters. However, no loss of $T$. pseudonana cells was observed in the controls, so it appears that viral lysis was not significant; more likely, Fe was released through cell metabolism. Active Fe efflux has been previously reported for this phytoplankton strain: Miao \& Wang (2006) measured a rate constant for Fe efflux from T. pseudonana cells of 0.008 to $0.017 \mathrm{~h}^{-1}$. Given the observed intracellular Fe quotas, metal actively effluxed over the course of the grazing period from cells could account for 0.20 to $0.74 \mathrm{nM}$ Fe present in our controls. These calculated concentrations encompass the dissolved Fe actually measured in the control experiments $(0.30$ to $0.49 \mathrm{nM}$ ), indicating that active cellular efflux could well have been an important mechanism for $\mathrm{Fe}$ release.

The size-fractionation of $\mathrm{Fe}$ in the treatments and controls were similar, suggesting that dinoflagellate grazing did not alter colloid formation or dissolution significantly. These measurements were taken prior to the addition of EDTA and nutrients to regrowth flasks, so binding by this chelator cannot explain the similar size distributions. Inorganic Fe (hydr)oxide colloids would be unlikely to form during the $14 \mathrm{~h}$ incubation period in the presence of organic exudates. However, the Fe may be bound by organic colloids which form spontaneously from organic compounds exuded by the phytoplankton (Chin et al. 1998). Poorvin et al. (2004) also observed measurable release of Fe from phytoplankton and bacteria in non-viral control cultures, and found nearly half of the Fe released from heterotrophic bacteria in the absence of viruses to be in a colloidal (>30 kDa) form. It is possible that some of the colloidal Fe present in the treatments and controls was viral particles. Iron is known to sorb to viruses (Daughney et al. 2004), which may have been inadvertently introduced to the grazing media with the Thalassiosira pseudonana prey which achieved high cell densities during labeling. Only a small portion $(<5 \%)$ of the total remineralized Fe was accumulated by phytoplankton during the $48 \mathrm{~h}$ regrowth period, and it is not possible to determine which fraction was utilized by the algal cells. However, there is growing evidence that colloidal $\mathrm{Fe}$ is bioavailable to phytoplankton (Nishioka \& Takeda 2000, Chen \& Wang 2001, Hurst \& Bruland 2007).

\section{Oceanographic context}

Remineralized Fe may account for a larger fraction of the 'dissolved' $(<0.45 \mu \mathrm{m})$ Fe pool than generally acknowledged. Much of the research into the bioavailability and behavior of this Fe has focused on siderophores as model Fe-binding ligands (e.g. Maldonado \& Price 1999, Barbeau et al. 2001b), and Fe-binding functional groups characteristic of siderophores have been detected in natural waters (Macrellis et al. 2001). However, Fe has been shown to cycle rapidly through plankton groups in the field (Hutchins et al. 1993, Hutchins \& Bruland 1994), and models of Fe cycling in HNLC regions such as the equatorial Pacific indicate that as much as $90 \%$ of primary production is supported by recycled Fe (Landry et al. 1997). Regenerated Fe production is equally important in the South- 
ern Ocean (Boyd et al. 2005, Strzepek et al. 2005). The turnover times for $\mathrm{Fe}$ in these environments are short: between $7 \mathrm{~h}$ and several days for the equatorial Pacific and Southern Ocean (Price et al. 1994, Boyd et al. 2005). Given the slow dissociation kinetics of 'recycled' Fe ligands such as porphyrins $\left(0.7\right.$ to $12 \times 10^{-6} \mathrm{~s}^{-1}$; Witter et al. 2000), most Fe likely exists in this form when it is accessed by phytoplankton. It is therefore notable that this fraction is bioavailable to common eukaryotic phytoplankton on timescales of hours.

\section{CONCLUSIONS}

The present study demonstrates that protozoa remineralize Fe from marine phytoplankton prey, and the remineralized $\mathrm{Fe}$ is bioavailable to phytoplankton. It is one of the few studies to directly assess the bioavailability of remineralized Fe under controlled laboratory conditions and the first to use heterotrophic protists with live phytoplankton prey. The uptake experiments did not rely upon model compounds; instead, natural $\mathrm{Fe}$ compounds were produced through the grazing activity of Oxyrrhis marina. Results support previous findings that several important groups of eukaryotic phytoplankton such as diatoms and coccolithophores can readily access remineralized Fe. These results are important to our understanding of Fe cycling in the ocean and the role of heterotrophic protists in this cycle. Characterization studies of organic Fe-binding ligands released by microzooplankton grazing are needed to better constrain the chemical speciation of Fe and its effects on the global Fe and carbon cycles.

Acknowledgements. Support for this work was provided by start-up funds from the University of South Carolina. We thank T. Richardson for helpful feedback on an earlier version of the manuscript. The manuscript was also improved significantly by the thoughtful comments of 3 anonymous reviewers. The open ocean seawater used in the experiments was collected on a cruise funded by NSF OCE-0437366 to J. Bernhard of the Woods Hole Oceanographic Institution.

\section{LITERATURE CITED}

Achilles KM, Church TM, Wilhelm SW, Luther GW, Hutchins DA (2003) Bioavailability of iron to Trichodesmium colonies in the western subtropical Atlantic Ocean. Limnol Oceanogr 48:2250-2255

Barbeau KA, Moffett JW (1998) Dissolution of iron oxides by phagotrophic protists: using a novel method to quantify reaction rates. Environ Sci Technol 32:2969-2975

Barbeau K, Moffett JW, Caron DA, Croot PL, Erdner DL (1996) Role of protozoan grazing in relieving iron limitation of phytoplankton. Nature 380:61-64
Barbeau K, Kujawinski EB, Moffett JW (2001a) Remineralization and recycling of iron, thorium and organic carbon by heterotrophic marine protists in culture. Aquat Microb Ecol 24:69-81

Barbeau K, Rue EL, Bruland KW, Butler A (2001b) Photochemical cycling of iron in the surface ocean mediated by microbial iron(III)-binding ligands. Nature 413:409-413

Bowie AR, Maldonado MT, Frew RD, Croot PL and others (2001) The fate of added iron during a mesoscale fertilisation experiment in the Southern Ocean. Deep Sea Res II 48:2703-2743

> Boyd PW, Law CS, Hutchins DA, Abraham ER and others (2005) FeCycle: attempting an iron biogeochemical budget from a mesoscale $\mathrm{SF}_{6}$ tracer experiment in unperturbed low iron waters. Glob Biogeochem Cycles 19, GB4S20, doi: 10.1029/2005GB002494

Boye $M$, Aldrich A, van den Berg CMG, de Jong JTM and others (2006) The chemical speciation of iron in the northeast Atlantic Ocean. Deep Sea Res I 53:667-683

Bruland KW, Lohan MC (2003) Controls of trace metals in seawater. In: Elderfield $\mathrm{H}$ (ed) The oceans and marine geochemistry: treatise on geochemistry. Elsevier, Oxford, p 23-47

Castruita M, Shaked Y, Elmegreen LA, Stiefel EI, Morel FMM (2008) Availability of iron from iron-storage proteins to marine phytoplankton. Limnol Oceanogr 53:890-899

Chen M, Wang WX (2001) Bioavailability of natural colloidbound iron to marine plankton: influences of colloidal size and aging. Limnol Oceanogr 46:1956-1967

Chin WC, Orellana MV, Verdugo P (1998) Spontaneous assembly of marine dissolved organic matter into polymer gels. Nature 391:568-572

Daughney CJ, Chatellier X, Chan A, Kenward P, Fortin D, Suttle CA, Fowle DA (2004) Adsorption and precipitation of iron from seawater on a marine bacteriophage (PWH3A-P1). Mar Chem 91:101-115

de Baar HJW, Boyd PW, Coale KH, Landry MR and others (2005) Synthesis of iron fertilization experiments: from the iron age in the age of enlightenment. J Geophys Res C 110, C09S16, doi: 10.1029/2004JC002601

> Gerringa LJA, Veldhuis MJW, Timmermans KR, Sarthou G, de Baar HJW (2006) Co-variance of dissolved Fe-binding ligands with phytoplankton characteristics in the Canary Basin. Mar Chem 102:276-290

> Gledhill M, McCormack P, Ussher S, Achterberg EP, Mantoura RFC, Worsfold PJ (2004) Production of siderophore type chelates by mixed bacterioplankton populations in nutrient enriched seawater incubations. Mar Chem 88: $75-83$

Gobler CJ, Hutchins DA, Fisher NS, Cosper EM, SanudoWilhelmy SA (1997) Release and bioavailability of C, N, P, $\mathrm{Se}$, and Fe following viral lysis of a marine chrysophyte. Limnol Oceanogr 42:1492-1504

Guillard RRL, Sieracki MS (2005) Counting cells in cultures with the light microscope. In: Andersen RA (ed) Algal culturing techniques. Elsevier Academic Press, Boston, MA, p 239-252

Hering JG, Morel FMM (1989) Slow coordination reactions in seawater. Geochim Cosmochim Acta 53:611-618

Hertkorn N, Benner R, Frommberger M, Schmitt-Kopplin P and others (2006) Characterization of a major refractory component of marine dissolved organic matter. Geochim Cosmochim Acta 70:2990-3010

Hudson RJM, Morel FMM (1990) Iron transport in marine phytoplankton: kinetics of cellular and medium coordination reactions. Limnol Oceanogr 35:1002-1020

Hurst MP, Bruland KW (2007) An investigation into the 
exchange of iron and zinc between soluble, colloidal, and particulate size-fractions in shelf waters using low-abundance isotopes as tracers in shipboard incubation experiments. Mar Chem 103:211-226

Hutchins DA, Bruland KW (1994) Grazer-mediated regeneration and assimilation of $\mathrm{Fe}, \mathrm{Zn}$, and $\mathrm{Mn}$ from planktonic prey. Mar Ecol Prog Ser 110:259-269

Hutchins DA, DiTullio GR, Bruland KW (1993) Iron and regenerated production: evidence for biological iron recycling in two marine environments. Limnol Oceanogr 38: 1242-1255

Hutchins DA, Witter AE, Butler A, Luther GW (1999) Competition among marine phytoplankton for different chelated iron species. Nature 400:858-861

La Roche J, Boyd PW, McKay RML, Geider RJ (1996) Flavodoxin as an in situ marker for iron stress in phytoplankton. Nature 382:802-805

Landry MR, Barber RT, Bidigare RR, Chai F and others (1997) Iron and grazing constraints on primary production in the central equatorial Pacific: an EqPac synthesis. Limnol Oceanogr 42:405-418

Macrellis HM, Trick CG, Rue EL, Smith G, Bruland KW (2001) Collection and detection of natural iron-binding ligands from seawater. Mar Chem 76:175-187

Maldonado MT, Price NM (1999) Utilization of iron bound to strong organic ligands by plankton communities in the subarctic Pacific Ocean. Deep Sea Res II 46:2447-2473

Maldonado MT, Price NM (2001) Reduction and transport of organically-bound iron by Thalassiosira oceanica (Bacillariophyceae). J Phycol 37:298-309

Maldonado MT, Strzepek RF, Sander S, Boyd PW (2005) Acquisition of iron bound to strong organic complexes, with different Fe binding groups and photochemical reactivities, by plankton communities in Fe-limited subantarctic waters. Glob Biogeochem Cycles 19, GB4S23, doi: 10. 1029/2005GB002481

Martin JH (1990) Glacial-interglacial $\mathrm{CO}_{2}$ change: the iron hypothesis. Paleoceanography 5:1-13

Mazmanian SK, Skaar EP, Gaspar AH, Humayun M and others (2003) Passage of heme-iron across the envelope of Staphylococcus aureus. Science 299:906-909

Miao AJ, Wang WX (2006) Fulfilling iron requirements of a coastal diatom under different temperatures and irradiances. Limnol Oceanogr 51:925-935

> Nishioka J, Takeda S (2000) Change in the concentrations of iron in different size fractions during growth of the oceanic diatom Chaetoceros sp.: importance of small colloidal iron. Mar Biol 137:231-238

Peers G, Price NM (2006) Copper-containing plastocyanin

Editorial responsibility: Klaus Jürgens,

Rostock, Germany used for electron transport by an oceanic diatom. Nature 441:341-344

Poorvin L, Rinta-Kanto JM, Hutchins DA, Wilhelm SW (2004) Viral release of iron and its bioavailability to marine plankton. Limnol Oceanogr 49:1734-1741

Price NM, Ahner BA, Morel FMM (1994) The equatorial Pacific Ocean: grazer-controlled phytoplankton populations in an iron-limited ecosystem. Limnol Oceanogr 39: $520-534$

Rao AU, Carta LK, Lesuisse E, Hamza I (2005) Lack of heme synthesis in a free-living eukaryote. Proc Natl Acad Sci USA 102:4270-4275

Rue EL, Bruland KW (1997) The role of organic complexation on ambient iron chemistry in the equatorial Pacific Ocean and the response of a mesoscale iron addition experiment. Limnol Oceanogr 42:901-910

Sato M, Takeda S, Furuya K (2007) Iron regeneration and organic iron(III)-binding ligand production during in situ zooplankton grazing experiment. Mar Chem 106:471-488

Soria-Dengg S, Horstmann U (1995) Ferrioxamines B and E as iron sources for the marine diatom Phaeodactylum tricornutum. Mar Ecol Prog Ser 127:269-277

Strom SL (1993) Production of pheopigments by marine protozoa: results of laboratory experiments analyzed by HPLC. Deep Sea Res I 40:57-80

Strzepek RF, Maldonado MT, Higgins JL, Hall J, Safi K, Wilhelm SW, Boyd PW (2005) Spinning the 'Ferrous Wheel': the importance of the microbial community in an iron budget during the FeCycle experiment. Glob Biogeochem Cycles 19, GB4S26, doi: 10.1029/2005GB002490

> Sunda WG, Huntsman SA (1995) Iron uptake and growth limitation in oceanic and coastal phytoplankton. Mar Chem 50:189-206

Sunda WG, Huntsman SA (1998) Processes regulating cellular metal accumulation and physiological effects: phytoplankton as model systems. Sci Total Environ 219:165-181

Timmermans KR, Gerringa LJA, de Baar HJW, van der Wagt B and others (2001) Growth rates of large and small Southern Ocean diatoms in relation to availability of iron in natural seawater. Limnol Oceanogr 46:260-266

- Tovar-Sanchez A, Sanudo-Wilhelmy SA, Garcia-Vargas M, Weaver RS, Popels LC, Hutchins DA (2003) A trace metal clean reagent to remove surface-bound iron from marine phytoplankton. Mar Chem 82:91-99

- Witter AE, Hutchins DA, Butler A, Luther GW (2000) Determination of conditional stability constants and kinetic constants for strong model Fe-binding ligands in seawater. Mar Chem 69:1-17

Zar JH (1996) Biostatistical analysis. Prentice Hall, Upper Saddle River, NJ

Submitted: February 20, 2008; Accepted: November 24, 2008 Proofs received from author(s): February 12, 2009 